\title{
Female leaders in the 21st century in a masculine world
}

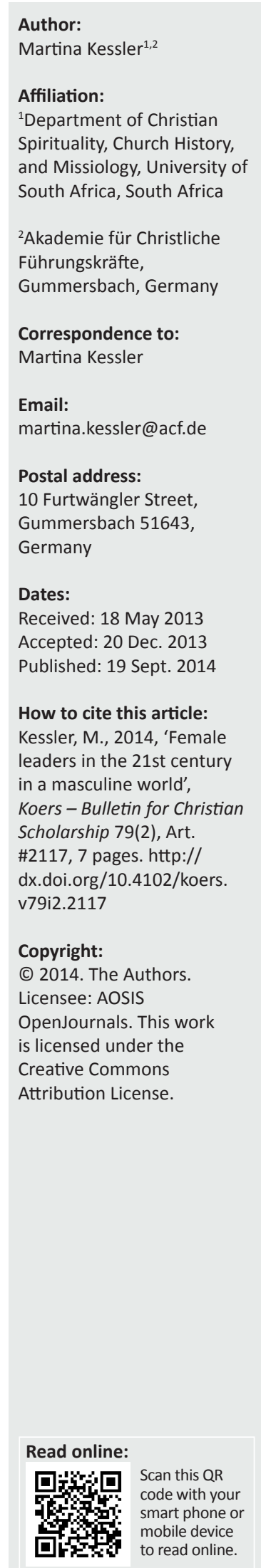

The 21st century shows an increase in the number of women occupying leadership positions. The challenge is: How do they lead in a context which is still male dominated? Often female leaders simply try to copy the male leadership style they are familiar with. But sometimes, in doing so, they lose their femininity and the organisation misses out on the specific opportunities of female leadership. One aim of this article is to discuss the opportunities and strengths of a female leadership style such as pro-social behaviour and a panorama view. We will also deal with the issue of how women approach power and the power bases women would typically use. One conclusion is that we need the benefits of both male and female leadership for the 21st century.

Vroulike leiers in die 21ste eeu in 'n manlike wêreld. Die 21ste eeu toon ' $n$ toename in die aantal vroue in leierskapsposisies. Die uitdaging is: Hoe kan hulle lei in 'n konteks wat steeds deur mans oorheers word? Dikwels probeer vroulike leiers eenvoudig die manlike leierskapstyl waarmee hulle vertroud is, naboots. As 'n gevolg verloor vroue soms hul vroulikheid en organisasies verloor die spesifieke geleenthede wat vroulike leierskap bied. Een doel van hierdie artikel is om die geleenthede en sterkpunte van 'n vroulike leierskapstyl, soos pro-sosiale gedrag en 'n panorama-uitsig, te bespreek. Ons sal ook kyk na die kwessie van vroue se benadering tot mag en die magsbasisse wat vroue tipies gebruik. Een gevolgtrekking is dat ons die voordele van beide manlike en vroulike leierskap vir die 21ste eeu benodig.

\section{Introduction}

This article is about the challenges that face women who lead in cultural contexts that are still shaped by masculine values. As a woman living in Germany, I am writing from the perspective of German women. Mine was one of the many voices at the Christian Leadership Conference held in Pretoria, South Africa, in February 2013. One starting point of this article is the empirical study I did during my master's thesis, 'The erotic attraction of power? Authentic living - a challenge in Christian missions' (Kessler 2008). In this work I studied single, female leaders with regard to their sexual temptability - the ability to tempt a female in connection with her leadership position. ${ }^{1}$ The issue of female leadership in a masculine world was also a focal point. What follows are some of the results of the study.

I am aware of the fact that today there are many different worldviews on gender issues. On the one hand, more and more people see 'womanhood' and 'manhood' as pure social constructs (Becker \& Kortendiek 2010); on the other hand, published research results demonstrate the biological differences between men and women (Gerl-Falkovitz 2009). For example, cardiologists recently discovered that women show different symptoms of heart attacks than men (Netdoktor. de 2011). This was not known in the 1980s when I did my nursing degree. Since the research in medical books only focussed on the male body and its symptoms, heart attacks in women were often not even detected. The new research led to the insight that medical descriptions of heart attacks should differentiate between men and women.

In this article I will focus on the literature which highlights the differences between men and women. It is my belief that men and women are different in some aspects, but this should not lead to different positions in hierarchy. I think that both men and women have their strengths and their weaknesses, but together they can change the world.

I define female leadership as the way in which women live out their femininity whilst leading. Feminist leadership is a political approach which demands that more women occupy leadership

1.Of course, there is no automatic link between leadership position and sexual temptability, but still many women in leadership positions occasionally receive sexual offers from men. These offers can be successful only if there is an intrinsic openness on the woman's side. 
positions. This aspect is not dealt with in this article. ${ }^{2}$ The fear that women will be discriminated against once they are described with female attributes hampers the development of a theory for female leadership. Two forces are at work here. On the one hand, differences between men and women cannot be the basis of any form of discrimination; but, on the other hand, justice is not done to women (and men) if their biology, and the consequences it bears, is simply ignored. Rather, it is desirable that men see themselves as men and women see themselves as women in their respective leadership roles.

Authors have different views on what constitutes typical womanhood - including the female style of leadership. Some authors (e.g. Tannen 1990, 1991, 1999, 2005) root it solely in sociology, whereas others assume evolutionary or biological reasons for the differences (e.g. Beach 2008; Bischof-Köhler 2002). Today we can say that these authors belong to difference-based feminism and constructivism. Authors such as Haucke \& Krenovsky (2003) do not make any suggestions. They would invite women to use their natural female impulses instead of copying male behaviour.

According to Glaesner (2007), there are no differences at all between male and female leadership. She researches, for example, the literature of Max Weber (1972), Fred Fiedler (1967) and Fiedler \& Mai-Dalton (1995) on leadership. However, the lack of literature on female leadership is a weak argument. For one, any argument based on silence is a weak argument, but, more importantly, these male authors were not clued up on female leadership, mostly because female leaders were rare and they often adopted a male leadership style. As an example of this typical onesided male perspective, we may quote the famous German theologian, Jürgen Moltmann ([1971] 2005:9), who admitted his former fallacy later on in a new foreword to his book, Mensch: Christliche Anthropologie in den Konflikten der Gegenwart. In 1971 he presumed to write about human beings as such and he as a man would have been able to say what had to be said. This fallacy was cured by his wife, Elisabeth Moltmann, who introduced him to Feminist Theology. In 2005 Jürgen Moltmann pointed out that anthropology had to take the duality of man and woman into account. This fallacy is also typical of leadership literature. Authors write about leadership per se, but they present only the male perspective.

There are many different leadership styles such as authoritarian leadership, democratic leadership, visionary leadership and so forth (Mahlmann 2011). I do not claim that female leadership is yet another one. Just like any other leader, a woman in a leadership position will - consciously or unconsciously - exercise one of these leadership styles, but she will do it in a specific, female way. And a man in a leadership position will exercise the same leadership style in a different way. All leaders have to use a power base to be able to lead (Kessler 2010:539-544). Women can live in and

2.It is interesting to note that in the German literature on leadership no distinction is made between female and feminist leadership styles (e.g. Asgodom 1999; Assig 2001; Storch 2002). execute any power base, but they will do it in a female way different from their male colleagues.

You may remember Golda Meir (1898-1978), former Israeli Prime Minister ${ }^{3}$, and Margaret Thatcher (1925-2013), former Prime Minister of the United Kingdom. ${ }^{4}$ Both were women, but they came across as quite masculine. Thatcher was also called the Iron Lady. We are now living in a new era. The Chancellor of Germany, Angela Merkel, leads in a masculine world, but she comes across as quite feminine. The press has documented how she changed her haircut to look more feminine as she entered her chancellorship. In the 1990s the public perceived her as an androgynous scientist; today they see her as a female politician.

It is often postulated that women are better leaders (Assig 2001). This theory, which is based on difference-based feminism, has not yielded much influence in Germany. The debate on how high the percentage of female leaders should be still remains a political issue (Seitz et al. 2013:36-47). As explained above, the focus of this paper is on a female leadership style and not on feminist leadership. The intention is not to replace male with female leaders, but to make female leadership skills accessible to all.

\section{What is meant by 'masculine world'?}

A masculine world means a context or a culture which is dominated by a masculine worldview, including traditional masculine values. The Dutch sociologist, Geert Hofstede (2001), did a comprehensive study on human values in over 50 countries all over the world. From his data emerged various cultural dimensions that, depending on their constellation, give each national culture its characteristic imprint and worldview. In one of these dimensions, Hofstede distinguishes between two opposing characteristics of culture he describes as 'femininity' and 'masculinity'. Feminine culture is described as compassionate, tolerant, and having sympathy for the weak. Gender roles in such a culture are not so clearly separated. It is acceptable, even in a professional environment, for a man to be 'feminine'- sensitive, modest and valuing quality of life (Hofstede 2001:133). Hofstede (2001) defines a society as:

masculine when emotional gender roles are clearly distinguished from one another: Men ought to be dominant, hard and materialistic in orientation, women, however, must be modest, sensitive and value quality of life. (p. 115, my translation ${ }^{5}$ )

'Masculine' values such as achievement, material success and economic growth control life in general and thus also professional life.

3.Israeli politician from 1956-1965. Minister for Foreign Affairs from March 1969 to June 1974. She is so far the only female minister to serve in Israel.

4.Her full name was Margaret Hilda Thatcher, Baroness Thatcher of Kesteven, British politician. She led the Conservative Party from 1975 to 1990 and from May 1979 to November 1990 she was the Prime Minister of the United Kingdom. She was the first woman to hold this office and stayed in it longer than all her male predecessors since the beginning of the 19th century.

5.'Maskulinität kennzeichnet eine Gesellschaft, in der die Rollen der Geschlechter Maskulinität kennzeichnet eine Gesellschaft, in der die Rollen der Geschlechter
klar gegeneinander abgegrenzt sind: Männer haben bestimmt, hart und materiell klar gegeneinander abgegrenzt sind: Männer haben bestimmt, hart und materiell
orientiert zu sein, Frauen müssen bescheidener, sensibler sein und Wert auf Lebensqualität legen' (Hofstede 2001:115). 
The GLOBE-study of 62 societies (House et al. 2004) is based on Hofstede's (2001) definition although it comes to a more differentiated result. Interestingly, there is a similarity between South Africa and Germany: there are distinct people groups in both countries. In Germany there are differences between East Germany, a formerly communist area, and West Germany; and in South Africa there are differences between the various ethnic groups. ${ }^{6}$

According to the GLOBE-study of 62 societies, the social practice of gender equality in black South Africa (score 3.66) is more masculine than in white South Africa (3.27) and more masculine in western Germany (3.10) than in eastern Germany (3.06). In this category Hungary (4.08), Russia (4.07) and Poland (4.02) are the most masculine and South Korea (2.50), Kuwait (2.58) and Egypt (2.81) the least masculine (House et al. 2004:365).

The desire for gender equality amongst the people groups is as follows: eastern Germany (4.90) lies ahead of western Germany (4.89) and white South Africa (4.60) is clearly ahead of black South Africa (4.26). The desire for more masculinity is the highest in England (5.17), Sweden (5.15) and Ireland (5.14) and least pronounced in Egypt (3.18), Qatar (3.38) and Kuwait (3.45) (2004:366). ${ }^{7}$

\section{The woman as leader in the 21st century}

Women in leadership in a masculine world are faced with the danger that their performance will be measured according to masculine values, or that they will also equate success with internalised male values. This danger can be avoided only if women recognise and incorporate their own specific female strengths.

The question that naturally arises is: Can we even make general statements about female-specific strengths or are strength and weakness profiles only a question of personality? Of course personality plays a large role and shapes leadership potential; of course a task-oriented woman will behave differently from a relation-oriented woman and an extroverted woman will be perceived differently from an introverted woman. But the fact remains that every woman worldwide shares a similar biological starting position. The various personality traits develop from this universal foundation. The focus of this article is to describe what is typical of female leadership and not to dwell on differences in individual personality traits. To what extent leadership personality-specific and gender-specific characteristics are interrelated and intertwined cannot be sufficiently covered in this article. One thing is clear: there is the steady, introverted, more relationship-oriented male boss who leads his company with sensitivity, and the dominant, extroverted, more distant female boss who challenges her employees and prepares 6.In Canada and Switzerland distinctions are made according to language groups.

7. As a side note, Namibia, a country in southern Africa but with many ethnic German immigrants, ranks in the first category ('as is') with a score of 3.88, higher than black South Africa, and in the second category ('should be') with a score of 4.25 , directly below black South Africa. the organisation for future innovations; and yet a dominant woman will be more feminine than a dominant man (Seiwert \& Gay 1999:93-99). Therefore, the question of personality can be left aside this time.

\section{The strengths of a woman in leadership}

Various sociological studies have confirmed that the strength of a woman lies in her relationship orientation (Bischof-Köhler 2002; Haucke \& Krenovsky 2003; Tannen 1990, 2005); it also shapes women's understanding of leadership. God created humankind in his divine image as man and woman (Gn 1:26-27). Gender-specific differences can be detected as early as 16 months of age (Bischof-Köhler 2002:8). Even though many differences between men and women can be linked to gender-typical socialisation, there are other differences that cannot be changed either by medical means or by socialisation. Even if females possess some typically male traits, they remain female in every cell of their body, which results in particular strengths and opportunities but also in limitations.

Some specific aspects of female leaders are shown in Table 1.

\section{Perception \\ Strengths and opportunities}

Perception is one strength of relationship orientation: Women try to take everything and everyone into consideration. Since women are typically very relationship-oriented, they have developed a strong social competence. This competence allows women to assess a situation correctly and collect information from all sides. Their willingness to consider all perspectives of a situation gives them the power of persuasion.

It becomes especially obvious in meetings that women usually complement their goal-oriented strategies with their panoramic view. Moreover, $80 \%$ of women think predicatively where most men (65\%) think functionally. For example, in response to the statement "dogs bark", the predicative thinker suggests a connection: 'cats meow', 'birds sing'. The functional thinker looks at the purpose: 'dogs guard the house' (Bischof-Köhler 2002:257). The predicative panoramic view gives leadership a comprehensive perspective and potentially protects it from pitfalls. The organisation will consequently be more secure and more beneficial to all.

TABLE 1: Strengths and limitations of female leaders.

\begin{tabular}{lll}
\hline Aspect & Strength or opportunity & Limitations \\
\hline Perception & Panoramic view & Lack of focus \\
Dedication & Pro-social engagement & Self-abandonment \\
Power & Able to share power & Will not accept power \\
Success & Shares success & Doubts self-competence \\
Networking & Connects projects and people & Networking as a goal \\
\hline
\end{tabular}

Source: Kessler, M., 2008, 'Macht Macht erotisch? Authentisch leben eine Herausforderung in der christlichen Mission: Am Beispiel sexueller Versuchlichkeit weiblicher, lediger, in der christlichen Mission: Am Beispiel sexueller Versuchlichkeit weiblicher, lediger,
heterosexuelle Führungskrätte in Deutschland', Dissertation Master of Theology in Missiology, University of South Africa 


\section{Limitations}

Those who take everyone and everything into consideration do not tend to get very far. Women can get bogged down if they are not focused on the goal.

\section{Solution}

Predicative thinking is as important as functional thinking. They can be complementary if both types of thinking are represented and if they continue to exchange with each other.

\section{Dedication}

\section{Strengths and opportunities}

Women usually lead with great dedication. For them it has less to do with their career and more to do with the people, project, and the organisation. Bischof-Köhler (2002:347) speaks in this context of pro-social engagement, which means that women draw their self-confidence from qualities such as 'caring for others, maintaining personal relationships, and taking on responsibility for the physical and emotional well-being of others' (ibid: 342, my translation ${ }^{8}$ ). They value talking about important personal issues, listening attentively and supporting and encouraging others who have problems (ibid: 343-344; Tannen 1990:73-90). Women try to be sympathetic, understanding and sensitive towards others and feel committed and responsible towards others. This includes the desire to offer practical help, support those in need, give guidance and share.

Newcomers are welcomed, informed and properly introduced. Women 'clearly reveal in their behaviour their need to do something good for others' (Bischof-Köhler 2002:346, my translation ${ }^{9}$ ). They are focused on social interactions which make it easy for others to engage with them (ibid: 355-356). Women often struggle to find the right balance between the desire to take care of the other and the awareness of one's own competence. When this balance is successfully achieved, their pro-social engagement becomes a source of healthy self-confidence.

\section{Limitations}

According to Ecker (2002:47): 'For women, others are more important than themselves. Then, and only when they no longer have any time, strength and energy do they attend to themselves' (my translation ${ }^{10}$ ). Who the 'others' are depends on their surroundings. Women who live in several environments often manage them in such a way that they themselves pay a price. Women tend to give the 'shirt off their backs' (ibid:47), even when it means they no longer have anything left for themselves. In the worst case scenario, they sacrifice themselves for an important task - sometimes even to the point of burnout. Women gladly make suggestions 8.'Fürsorglichkeit, Pflege persönlicher Beziehungen, Verantwortung für das Wohlergehen und die seelische Verfassung anderer' (Bischoff-Köhler 2002:342).

9.'bringen in ihren Verhaltensweisen also deutlich das Bedürfnis zum Ausdruck, dem anderen etwas Gutes zu tun' (Bischoff-Köhler 2002:346).

10.'Frauen nehmen erst die anderen wichtig. Dann kommt lange nichts, und dann, an letzter Stelle, wenn keine Zeit, Kraft und Energie mehr bleiben, räumen sie für sich einen Platz ein' (Ecker 2002:47). or give orders that protect the wellbeing of others, thereby assuming responsibility for them.

\section{Solution}

Women should reflect on their lives and live in a tension between relaxation and commitment. Even Jesus, who calls us to completely surrender ourselves (Mt 11:30) also tells us to rest (Lk 10:40-42). Women should take advantage of coaching, supervision and mentoring opportunities. They should also be aware that the propensity for self-sacrifice can be reinforced by a corresponding personality structure.

\section{Power \\ Strengths and opportunities}

Women use their power to the benefit of all. They want to include everyone, which often leads to a high degree of satisfaction amongst employees. When conflicts arise between ranks, women generally show more thoughtfulness because it involves relationships. They prefer to establish hierarchy as a result of discussion (Bischof-Köhler 2002:314). This serves the overall process and offers everyone involved transparency and the opportunity to contribute to the organisation. Tasks are distributed according to strengths or gifting.

In all-women groups, privileges are not usually fought for but rather granted and can, therefore, be withdrawn. These concessions are not generally given once and for all, but newly clarified according to each new situation. Women prefer egalitarian structures and think more in networks than in hierarchies (Bischof-Köhler 2002:316-319).

To have power and admit weakness is not a contradiction for women. Women can, for example, without difficulty, admit when they do not know something (Tannen 1995:20). They also admit their ignorance, and seek out help, competence and expertise; they can also withhold their knowledge when needed. A question typical of the female style is: 'I do not understand; why is that?' (Diez 2006:no. 5, my translation ${ }^{11}$ ). And they can ask it without feeling they are losing face. This also serves the overall process and gives stability.

\section{Limitations}

Women want to exercise their power but at the same time fear that they will no longer be liked. They want to be 'the boss' and still be 'everyone's darling'. In this way, they weaken themselves because they cannot please everyone and still achieve their own goals. Even 'young girls exhibit fears of social exclusion and rejection due to unattractive appearances. Overall, the most important thing for a young girl is to be loved and admired' (Bischof-Köhler 2002:313, my translation ${ }^{12}$ ).

In conflict situations with men, women almost always give in (Hold, cited in Bischof-Köhler 2002:311), or they withdraw 11.'Verstehe ich nicht, warum ist das so?' (Diez 2006:15). 12. Ältere Mädchen äußerten Ängste vor sozialem Ausgeschlossenwerden und vor Zurückweisung wegen unattraktiver Erscheinung. Insgesamt ging es den Mädchen in erster Linie um das Geliebt- und Bewundertwerden' (Bischof-Köhler 2002:313). 
before the point of confrontation, usually sulking. Sulking is a worldwide behavioural expression that can be interpreted as 'being offended and threatening to break contact' (ibid:311, my translation $\left.{ }^{13}\right)$.

In workplaces there is usually a hierarchy even if women would prefer an egalitarian structure. The tension between preference and reality can create conflict. Since the hierarchy in all-women groups is constantly in flux, group members feel insecure, which makes continuous work difficult. Women in this context are described as competitive, critical, ambitious and difficult. It is specifically women in leadership positions who suffer from the non-acceptance of their female co-workers.

The indirect form of communication typical of women (Tannen 1999:101; 1991:41, 248) can impede their implementation of power, especially when dealing with male co-workers.

It is very common for women to justify their own power. I also notice this in my position at the Akademie für christliche Führungskräfte (AcF). When male leaders enquire about studying at AcF, they often signal to us: I already know everything, I just need your degree. The unstated question is actually: Are you (AcF) worth my time? However, when female leaders enquire about studying at $\mathrm{AcF}$, they often worry if they are good enough even though they often come highly qualified with plenty of experience. Understatement costs energy and undermines their position amongst coworkers. Whoever justifies her own power sabotages herself by lowering herself to the same level as her co-workers. At the same time, female leaders do not put themselves at the same level as other leaders and will, therefore, be less respected by the other leaders (Haucke \& Krenovsky 2003:13-25).

\section{Solution}

Women should reflect on their desire for power and make it very clear to themselves exactly how much power they want to have. How much power is needed to fulfil their current position and their desired position? Desire and reality should correlate as much as possible. Whoever has power must also use it (see Kessler 2010:535-537).

Whether a group is all-male or mix-gendered, the status of the female leader is usually established after a short time. She will be measured according to her competence. Female leaders should refrain from trying to please everyone. Firstly, it is not possible and it wastes a lot of energy. Secondly, it makes a leader vulnerable and open to manipulation. Thirdly, a leader who is loved by everyone has questionable leadership.

As explained above, female leaders will certainly not find 'heaven on earth' in all-female groups. If a female leader comes to the position with such an expectation, the resulting disappointment will be even greater.

13.beleidigt sein mit Drohung des Kontaktabbruchs interpretiert werden kann (Bischof-Köhler 2002:311)
When it comes to the question of power, there are four mandates to be aware of, because they build the basis for a leadership position (see Figure 1).

\section{Four mandates}

\section{Mandate from God}

For the Christian, God is the task giver. The Bible mentions two big tasks: the cultural mandate (Gn 1:26) and the missional mandate (Mt 28:18). All other tasks are derived from these (Schirrmacher 2002). It is not always so easy to recognise God's mandate within the specialised assignments. It is not sufficient that something is simply good, or that someone had a good idea. A mandate from God can only be identified by listening to God through his various means of communication.

\section{Mandate from herself - the woman}

The idea of giving oneself a mandate is particularly underdeveloped amongst women. Does she believe in herself enough and does she have enough self-respect for the task that lies ahead of her? Not every task that comes her way is the will of God. Therefore, she must be self-aware, paying attention to her competencies and her desire to lead. Even her readiness to suffer must be considered since it will be tested in a leadership position.

\section{Mandate from family or spouse (when applicable)}

The family's or spouse's positive attitude towards the woman's leadership role is a source of energy, whereas their disapproval of her leadership will drain her of energy. The majority of women will automatically pay attention to this aspect. Since women typically act pro-socially, they will seek their family's advice before accepting a new leadership position.

\section{Mandate from others (e.g. superiors, co- workers, clients, personal advisors)}

This mandate complements the previous three. Sometimes it is sufficient to receive this mandate from a single group. For other assignments, such a mandate is necessary from multiple groups. What is important is that the mandate

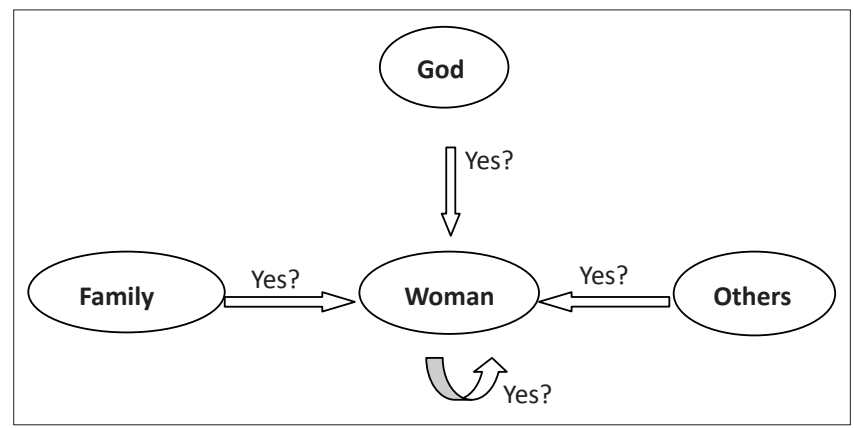

Source: Kessler, M. \& Marsch, A., 2007, 'Frauen führen anders', in J. Knoblauch \& H. Marquardt (eds.), Mit Werten Zukunft gestalten, pp. 151-164, Hänssler, Holzgerlingen FIGURE 1: The four mandates. 
comes from the group that is relevant to the assignment in question. It is important to seek advice from those who are objective about the situation: someone who is close but not directly affected by her decision. Those on the outside can sometimes see things those on the inside cannot.

\section{Success}

\section{Strengths and opportunities}

Building interpersonal relationships means success for women:

They need a certain closeness to experience and maintain confirmation and support. Their perceived role is marked by the struggle to keep intimacy and to avoid isolation ... Women also want to win status and avoid failure ... they pursue this goal under the guise of bonding. Intimacy is the key to their world of relationships. (Tannen 1991:20-21, my translation ${ }^{14}$ )

Their own success takes on more meaning if they include others in it. They constantly invite participation from others. The addition of these feminine strengths is of fundamental importance to a working environment and at every level of hierarchy.

The skills that tend to make women successful include in particular: endurance, perseverance, diligence, responsibility and strict adherence to proven strategies (Bischof-Köhler 2002:300). In order to arrive at a good decision they are prepared to deviate from their original conviction, to leave the beaten path and be innovative.

\section{Limitations}

Women can be too preoccupied with building relationships. It slows down their success, reduces their power within the organisation, and reduces their outside activities. Women tend not to see success as something they themselves have accomplished, but rather emphasise the circumstances or other people involved. This does not serve to strengthen their already weak sense of self-competence.

\section{Solution}

Women must learn to respect their own abilities. It is also beneficial to them to accept success as their own. When the need for relationships and business concerns are well balanced, it is to their own personal benefit and that of the organisation.

\section{Networking \\ Strengths and opportunities}

Women generally see themselves as part of a network of human relationships. Conversations are a means of developing closeness in which affirmation and support are given and received. According to Tannen (1991:20), it is typical for women to seek agreement.

14.Sie verhandeln über Nähe, bei der Bestätigung und Unterstützung gegeben und erhalten werden soll. Ihr Rollenverständnis ist geprägt vom Kampf um Bewahrung der Intimität und die Vermeidung von Isolation Frauen wollen auch Status gewinnen und Niederlagen vermeiden, ... das Ziel verfolgen sie unter dem Deckmantel der Bindung. Intimität ist der Schlüssel in ihrer Beziehungswelt (Tannen 1991:20-21)
Women contribute calmness and insight to a good overview perspective. This makes them wise in assessing opportunities and risks (Höhler 2006:16), a valuable quality for a company especially in times of bankruptcy or when there is a decline in financial donations. The involvement of as many partners as possible together with a clear structure and decisions regarding personnel are of enormous benefit to the whole project.

\section{Limitations}

Women tend to see networking as a means of success; it is, therefore, their number one priority. But networking can never be an end in itself (Höhler 2006:16). Someone who always wants to do networking does so in part, because he or she wants to limit risks and hard decisions. This is helpful to some extent, but when it becomes excessive it slows down the organisation.

\section{Solution}

Bock (2006:118) states: 'Choose your network well and do not get bogged down with too many commitments' (my translation $\left.{ }^{15}\right)$. Networks are the result of success, not the means to it.

\section{Conclusion}

I appreciate that the overall situation for women in leadership has already improved, and that an increasing number of women intentionally use their female strengths. The challenge today is for men and women to inform themselves about the differences between female and male leadership. I do not claim that either the female or the male leadership style is superior. They are of equal importance; but still different.

\section{To sum up:}

- In the 21st century women aspire to lead in a way that fits their womanhood.

- Typical female strengths are their panoramic view, their pro-social engagement, the willingness to share power, and networking.

- Female leaders should be aware of the drawbacks of these strengths (see Table 1). They should develop strategies to cope with these drawbacks. It would be useful for the superiors of women in leadership also to know about these strengths and drawbacks.

- Female leaders can act with self-assurance if they feel that they are in the right place. They should examine the four different mandates. It is not recommended to take a leadership position if they do not find a clear 'yes' to it. But they should become courageous leaders after having received a full 'yes' in each mandate.

Too often men and women work against each other and in that way exclude each other. Let us continue to work together to understand male and female leadership strengths 15. Suchen Sie sich ihr Netzwerk gut aus und verzetteln Sie sich nicht mit zu viele Verpflichtungen' (Bock 2006:118). 
as complementary; they might strive to work together and accept that the challenges posed by the other gender are actually constructive for the success of the overall organisation.

\section{Acknowledgements Competing interests}

The author declares that she has no financial or personal relationship(s) that may have inappropriately influenced her in writing this article.

\section{References}

Asgodom, S., 1999, Erfolg ist sexy: Die weibliche Formel für mehr Lust im Beruf, Kösel, München.

Assig, D., 2001, Frauen in Führungspositionen: Die besten Erfolgsrezepte aus der Praxis, Deutscher Taschenbuch Verlag, München.

Beach, N., 2008, Gifted to lead: The art of leading as a woman in the church, Zondervan, Michigan.

Becker, R. \& Kortendiek, B., 2010, Handbuch Frauen- und Geschlechterforschung: Theorien, Methoden, Empirie, 3rd edn., Verlag für Sozialwissenschaften, Wiesbaden. http://dx.doi.org/10.1007/978-3-531-92041-2

Bischof-Köhler, D., 2002, Von Natur aus anders: Die Psychologie der Geschlechtsunterschiede, Kohlhammer, Stuttgart.

Bock, P., 2006, 'Erfolgsfaktor Netzwerk', Emotion, August 2006, G+」 Emotion, München, 118.

Diez, G., 2006, 'Meinen die das ernst? Wie Anne Will und Marietta Slomka die Ironie in den Deutschen Fernsehjournalismus eingeführt haben', Die Zeit, no. 5, 26 January, p. 15.

Ecker, D., 2002, Aphrodites Töchter: Wie Frauen zu erfüllter Sexualität finden, 3rd edn., Kösel, München.

Fiedler, F., 1967, A theory of leadership effectiveness, McGraw-Hill, New York.

Fiedler, F. \& Mai-Dalton, R., 1995, 'Führungstheorien-Kontingenztheorien', in A. Kiese (ed.), Handwörterbuch der Führung, Enzyklopädie der Betriebswirtschaftslehre, vol. X, pp. 940-953.

Gerl-Falkovitz, H-B., 2009, Frau - Männin - Menschin: Zwischen Feminismus und Gender, Butzon \& Bercker, Kevelaer.
Glaesner, K., 2007, Geheimrezept weiblicher Führung? Hintergründe, Mythen und Konzepte zum weiblichen Führungsstil: Eine empirische Untersuchung beim deutschen Gewerkschaftsbund, Kassel University Press, Kassel.

Haucke, P. \& Krenovsky, A., 2003, Gelassen und souverän führen: Die Stärken des weiblichen Führungsstils, Kösel, Kempten.

Hofstede, G., 2001, Lokales Denken, globales Handeln: Interkulturelle Zusammenarbeit und globales Management, Deutscher Taschenbuch Verlag, München.

Höhler, G., 2006, 'Der Weg zu Erfolg: Leistung statt Plauderzirkel', Emotion, August 2006, G+J Emotion, München.

House, R., Hauges, P.J., Javidan, M., Dorfmann, P. W., Gupta, V. (eds.), 2004, Culture, leadership, and organizations: The GLOBE-study for 62 societies, Thousand Oaks/ SAGE Publications, London/New Delhi.

Kessler, M., 2008, 'Macht Macht erotisch? Authentisch leben - eine Herausforderung in der Christlichen Mission: Am Beispiel sexueller Versuchlichkeit weiblicher, lediger, heterosexuelle Führungskräfte in Deutschland', Master of Theology in Missiology dissertation, University of South Africa.

Kessler, V., 2010, 'Leadership and power', Koers - Bulletin for Christian Scholarship 75(3), 527-550. http://dx.doi.org/10.4102/koers.v75i3.95

Kessler, M. \& Marsch, A., 2007, 'Frauen führen anders', in J. Knoblauch \& H. Marquardt (eds.), Mit werten zukunft gestalten, pp. 151-164, Hänssler, Holzgerlingen.

Mahlmann, R., 2011, Führungsstile gezielt einsetzen. Mitarbeiterorientiert, situativ und authentisch führen, Beltz, Weinheim, Basel.

Moltmann, J., [1971] 2005, Mensch: Christliche Anthropologie in den Konflikten der Gegenwart, Kreuz-Verlag, Stuttgart .

Netdoktor.de, 2011, Herzinfarkt - Symptome, viewed 29 November 2011, from http://www.netdoktor.de/Krankheiten/Herzinfarkt/Symptome/HerzinfarktSymptome-7115.html

Schirrmacher, T., 2002, Führen in ethischer Verantwortung: Die drei Seiten jeder Entscheidung, Brunnen, Gießen.

Seitz, J., Göckner, T., Jung, B., Kowalski, M., Plewnia, U., Röll, T. et al., 2013, 'Wir wollen keine Quote', Focus (03)13, 36-47.

Seiwert, L.J. \& Gay, F., 1999, Das 1 x 1 der Persönlichkeit, 5th edn., GABAL, Offenbach.

Storch, M., 2002, Die Sehnsucht der starken Frau nach dem starken Mann, 6th edn., Goldman, München.

Tannen, D., 1990, Gender differences in topical coherence: Creating involvement in best friend's talk, Discours Processes.

Tannen, D., 1991, Du kannst mich einfach nicht verstehen: Warum Männer und Frauen aneinander vorbeireden, Kabel, Hamburg.

Tannen, D., 1999, Das hab' ich nicht gesagt: Kommunikationsprobleme im Alltag, Goldmann, München.

Tannen, D., 2005, Job-Talk: Wie Frauen und Männer am Arbeitsplatz miteinander reden, Kabel, Hamburg.

Weber, M., 1972, Wirtschaft und Gesellschaft: Grundriss der verstehenden Soziologie, Mohr Siebeck, Tübingen. 